\title{
Exome sequencing in primary melanoma identifies novel drivers of melanoma progression
}

\author{
Valentina Montagnani ${ }^{1 *}$, Matteo Benelli ${ }^{2}$, Alessandro Apollo ${ }^{1}$, Silvia Pandolfi ${ }^{1}$, Gianni Gerlini ${ }^{3}$, Lorenzo Borgognoni ${ }^{3}$, \\ Barbara Stecca ${ }^{1}$
}

From Melanoma Bridge Meeting 2014

Naples, Italy. 03-06 December 2014

\section{Background}

Melanoma is the most aggressive skin cancer due to its high metastatic propensity and resistance to most traditional chemotherapeutic drugs [1,2]. At early stage melanoma can be cured by surgical excision, whereas metastatic melanoma is a highly lethal condition. To understand melanoma progression is crucial identify mutations that are involved in making an individual melanoma competent for metastatic spread. The most frequent known oncogenic mutation in melanoma is $B R A F-\mathrm{V} 600 \mathrm{E}$ and several whole exome sequencing studies have revealed numerous other alterations [3-6]. It is well established that the aggressive behavior of melanoma is highly correlated with histological features, such as the thickness of the primary tumor and the mitotic index. Here we performed whole exome sequencing of 5 thin $(<1 \mathrm{~mm}$ in thickness) and 5 thick $(>4 \mathrm{~mm}$ in thickness) primary melanomas compared to matchednormal DNA.

\section{Materials and methods}

We have collected 10 fresh primary melanomas from 10 untreated patients: DNA samples from melanoma tissues and peripheral blood (normal DNA) were available from all of the recruited patients. Genomic DNA was extracted from tumor and peripheral blood samples using the QIAamp DNA Minikit, (Qiagen, Hilden, Germany). Extracted DNA was used for Next-Generation Sequencing analysis by Illumina.

\section{Results}

We confirmed recurrent somatic mutations in known melanoma-related genes, including BRAF, c-KIT, EGFR,

${ }^{1}$ Laboratory of Tumor Cell Biology, Core Research Laboratory - Istituto

Toscano Tumori, Florence, Italy

Full list of author information is available at the end of the article
PPP6C, MLL3 and several components of the glutamate signaling. In addition, we discovered mutations in genes not previously linked to this tumor, such as CSMD1, FGFR4 and components of the Hedgehog $(\mathrm{HH})$ signaling pathway. In particular, in a thick melanoma we found a novel activating mutation in the transcription factor GLI1, one of the final effectors of the HH signaling. Additionally, we identified candidate metastasisdriving mutations such as ADAMTS6, ADAMTS7, CHD9, MLL3, NALCN and TSC2 in the 3 thick melanomas that produced metastasis. Interestingly, we identified several regions of focal somatic copy-number alterations (SCNAs) that were altered at significantly higher frequency in thick compared to thin melanomas. Several gene families are comprised among these regions of focal SCNAs, including components of Notch, $\mathrm{HH}$ and $\mathrm{Wnt} / \beta$-catenin signaling pathways, BRAF, c-MYC and its cofactor PIM1, several ADAMs, EGFR and the HOX genes.

\section{Conclusion}

Our data identify potential drivers of melanoma progression, enhancing our understanding of the genomic complexity underlying melanoma.

\section{Authors' details \\ 'Laboratory of Tumor Cell Biology, Core Research Laboratory - Istituto Toscano Tumori, Florence, Italy. ${ }^{2}$ Diagnostic Genetic Unit, Laboratory Department, Careggi University Hospital, Florence, Italy. ${ }^{3}$ Plastic Surgery Unit, S.M. Annunziata Hospital - Regional Melanoma Referral Center, Istituto Toscano Tumori, Florence, Italy.}

Published: 15 January 2015

\section{References}

1. Chudnovsky Y, Khavari PA, Adams AE: Melanoma genetics and the development of rational therapeutics. J Clin Invest 2005, 115(4):813-824. 
2. Walia V, Mu EW, Lin JC, Samuels Y: Delving into somatic variation in sporadic melanoma. Pigment Cell Melanoma Res 2012, 25(2):155-170.

3. Wei X1, Walia V, Lin JC, Teer JK, Prickett TD, Gartner J, Davis S, NISC Comparative Sequencing Program, Stemke-Hale K, Davies MA,

Gershenwald JE, Robinson W, Robinson S, Rosenberg SA, Samuels Y: Exome sequencing identifies GRIN2A as frequently mutated in melanoma. Nat Genet 2011, 43(5):442-446.

4. Nikolaev SI, Rimoldi D, Iseli C, Valsesia A, Robyr D, Gehrig C, Harshman K, Guipponi M, Bukach O, Zoete V, Michielin O, Muehlethaler K, Speiser D, Beckmann JS, Xenarios I, Halazonetis TD, Jongeneel CV, Stevenson BJ, Antonarakis SE: Exome sequencing identifies recurrent somatic MAP2K1 and MAP2K2 mutations in melanoma. Nat Genet 2011, 44(2):133-139.

5. Stark MS, Woods SL, Gartside MG, Bonazzi VF, Dutton-Regester K, Aoude LG, Chow D, Sereduk C, Niemi NM, Tang N, Ellis JJ, Reid J, Zismann V, Tyagi S, Muzny D, Newsham I, Wu Y, Palmer JM, Pollak T, Youngkin D, Brooks BR, Lanagan C, Schmidt CW, Kobe B, Mackeigan JP, Yin H, Brown KM, Gibbs R, Trent J, Hayward NK: Frequent somatic mutations in MAP3K5 and MAP3K9 in metastatic melanoma identified by exome sequencing. Nat Genet 2011, 44(2):165-169.

6. Krauthammer M, Kong $\mathrm{Y}, \mathrm{Ha} B \mathrm{BH}$, Evans $\mathrm{P}$, Bacchiocchi A, McCusker JP, Cheng E, Davis MJ, Goh G, Choi M, Ariyan S, Narayan D, Dutton-Regester K, Capatana A, Holman EC, Bosenberg M, Sznol M, Kluger HM, Brash DE, Stern DF, Materin MA, Lo RS, Mane S, Ma S, Kidd KK, Hayward NK, Lifton RP, Schlessinger J, Boggon TJ, Halaban R: Exome sequencing identifies recurrent somatic RAC1 mutations in melanoma. Nat Genet 2012, 44(9):1006-1014.

doi:10.1186/1479-5876-13-S1-P2

Cite this article as: Montagnani et al:: Exome sequencing in primary melanoma identifies novel drivers of melanoma progression. Journal of Translational Medicine 2015 13(Suppl 1):P2.

\section{Submit your next manuscript to BioMed Central and take full advantage of:}

- Convenient online submission

- Thorough peer review

- No space constraints or color figure charges

- Immediate publication on acceptance

- Inclusion in PubMed, CAS, Scopus and Google Scholar

- Research which is freely available for redistribution

Submit your manuscript at www.biomedcentral.com/submit
Biomed Central 